\title{
Wnt/ $\beta$-catenin pathway as a potential prognostic and predictive marker in patients with advanced ovarian cancer
}

\author{
Lubomir Bodnar ${ }^{1 * \dagger}$, Aleksandra Stanczak ${ }^{2 \dagger}$, Szczepan Cierniak $^{3}$, Marta Smoter ${ }^{1}$, Marzena Cichowicz ${ }^{3}$, \\ Wojciech Kozlowski , Cezary Szczylik², Maciej Wieczorek² and Monika Lamparska-Przybysz²
}

\begin{abstract}
Background: $\beta$-catenin is the key protein in the WNT signalling pathway and it forms adherent junctions together with E-cadherin. In ovarian carcinoma, abnormal expression of $\beta$-catenin, E-cadherin and WNT-1 was observed, but their prognostic and predictive role is unclear. The aim of this study was to clarify the prognostic and predictive role of E-cadherin, $\beta$-catenin and WNT-1 in advanced epithelial ovarian carcinoma (AEOC).

Methods: The expression of E-cadherin, $\beta$-catenin and WNT-1 was determined by immunohistochemistry in AEOC. The correlation between expression of these proteins and progression-free survival (PFS) and overall survival (OS) was evaluated. Statistical analyses included Kaplan-Meier estimation, log-rank test, Spearman correlation and Cox proportional-hazards model.

Results: In ovarian cancer, intense expression of E-cadherin, $\beta$-catenin and WNT-1 was found. In multivariate analysis, strong membrane $\beta$-catenin expression was an independent unfavourable predictor for PFS (HR 2.19, $95 \% \mathrm{Cl} 1.09-4.39 ; p=0.028$ ), while in univariate analysis, strong membrane $\beta$-catenin expression was a prognostic factor for OS in patients with AOC $(p=0.039)$. In multivariate analysis, only resistance to first-line chemotherapy was an adverse independent prognostic factor for OS (HR 16.84; 95\% Cl 5.07-55.98; $\mathrm{p}<0.0001$ ). Additionally, strong membranous $\beta$-catenin expression was associated with resistance to platinum-based chemotherapy $(p=0.027)$.

Conclusions: These findings support that WNT/ $\beta$-catenin pathway and E-cadherin are important factors in advanced epithelial ovarian cancer.
\end{abstract}

Keywords: $\beta$-catenin, E-cadherin, WNT-1, Advanced ovarian cancer, Prognostic marker, Predictive marker

\section{Background}

Epithelial ovarian cancer (EOC) is the most common ovarian malignancy and accounts for $90 \%$ of cases of ovarian tumours [1]. In 2008, it is estimated that worldwide there were 224,747 women diagnosed with ovarian cancer and 140,163 deaths caused by ovarian cancer [2]. Ovarian carcinoma is the eighth most common cancer and the seventh most frequent cause of cancer death in women [2]. 63\% of EOC patients have widespread disease at presentation [3]. Despite surgery and platinum-based systemic treatment the

\footnotetext{
*Correspondence: lubo@esculap.pl

${ }^{\dagger}$ Equal contributors

${ }^{1}$ Department of Oncology, Military Institute of Medicine in Warsaw, 128

Szaserów Street, 04-141 Warsaw, Poland

Full list of author information is available at the end of the article
}

5-year survival for these patients is poor and accounts for $27 \%$ [3]. Therefore, prognostic and predictive factors for better management of EOC patients are required.

The most important prognostic factors for EOC include: age, performance status, histology type, International Federation of Gynaecology and Obstetrics (FIGO) stage and tumour grade $[4,5]$. However, biochemical and molecular markers are becoming important variables. The most significant marker is the level of cancer antigen 125 (CA-125), which is elevated in approximately $80 \%$ of advanced ovarian cancer cases [6]. Serum CA-125 level and its half-life are known to be correlated with OS and PFS [7-9]. Additionally, it is also a marker of response to chemotherapy [7,9-11].

\section{Biomed Central}


Recently, more attention has been focused on the molecular markers of the $\mathrm{WNT} / \beta$-catenin pathway, which is widely studied in EOC [12-14]. The $\mathrm{WNT} / \beta$-catenin pathway is triggered by WNT ligands, while $\beta$-catenin is the "heart" of the pathway and activates expression of many important proteins responsible for cell cycle, proliferation and survival e.g. cyclin D1, c-Myc. Moreover, $\beta$-catenin, together with E-cadherin, forms adherent junctions mediating cell adhesion [15]. In the absence of WNT ligands, $\beta$-catenin binds E-cadherin and forms complexes in the cell membrane. Free cytosolic $\beta$-catenin is recruited to a degradation complex constituted by anaphase promoting complex (APC) protein, Axin, glycogen synthase kinase $3 \beta$ (GSK3 $\beta$ ) and casein kinase I (CKI). GSK3 $\beta$ and CKI phosphorylate $\beta$-catenin, which is subsequently ubiquitinated by ubiquitin ligase protein ( $\beta \mathrm{TrCP}$ ) and degraded in the proteasome. WNT-1 binds to the frizzled/ lipoprotein receptor-related protein 5/6 (FZD/LRP5/6) receptors and triggers inactivation of the degradation complex. Unphosphorylated $\beta$-catenin is then transported to the nucleus, where it binds T-cell factor/lymphoid enhancer factor (TCF/LEF) and activates gene expression of proteins responsible for cell cycle, proliferation and survival [16].

Deregulation of $\mathrm{WNT} / \beta$-catenin pathway or altered expression of E-cadherin was found in many cancers as well as in EOC $[17,18]$. One of the possible mechanisms of $\mathrm{WNT} / \beta$-catenin pathway alteration involves mutations of the $\beta$-catenin gene (CTNNB1), which are found in endometrioid subtype of ovarian cancer [19-21]. Additionally, aberrant expression of $\beta$-catenin, E-cadherin and WNT-1 was observed in ovarian carcinoma [22-27]. The prognostic role of $\beta$-catenin and E-cadherin are disputed, while their impact on response to chemotherapy has never been evaluated in ovarian cancer patients.

The aim of this study was to determine the expression of $\beta$-catenin, E-cadherin and WNT-1 in advanced epithelial ovarian cancers and to assess the correlation of expression of the studied proteins with patient survival and response to platinum-based chemotherapy. We found changes in the expression of the studied proteins in ovarian cancer cells. Moreover, strong membrane $\beta$-catenin expression was identified as an unfavourable predictor for PFS and was associated with resistance to platinum-based chemotherapy for EOC patients.

\section{Methods}

\section{Patients}

We analysed medical records of all consecutive EOC patients treated in the Department of Oncology at the Military Institute of Medicine in Warsaw, Poland between March 2001 and December 2007. The inclusion criteria were as follows: (1) histologically confirmed advanced epithelial ovarian cancer in FIGO stage III-IV; (2) history of debulking surgery followed by first-line chemotherapy regimen: paclitaxel $\left(135 \mathrm{mg} / \mathrm{m}^{2}\right)$ with cisplatin $\left(75 \mathrm{mg} / \mathrm{m}^{2}\right)$ or paclitaxel $\left(175 \mathrm{mg} / \mathrm{m}^{2}\right)$ with carboplatin (AUC6), administered every 3 weeks for 6 cycles; (3) accessibility of primary tumour specimens and full medical data. Response to first-line chemotherapy according to RECIST criteria (version 1.0), PFS and OS were obtained from medical records and analysed retrospectively. This study was approved by the institutional review board of the Military Institute of Medicine in Warsaw (46/WIM/2009).

\section{Immunohistochemistry}

Immunohistochemical staining was performed on formalinfixed, paraffin-embedded primary tumours. Tissues were sectioned at $3 \mu \mathrm{m}$ and were mounted on Super Frost Ultra Plus ${ }^{\oplus}$ slides (Menzel GmbH\&co KG) and subjected to antigen retrieval in Target Retrieval Solution, pH 9 (DAKO) with PT Link (DAKO). Tissues were incubated with mouse monoclonal anti- $\beta$-catenin antibody (dilution 1:100, clone $\beta$-Catenin-1, DAKO), mouse monoclonal anti-E-cadherin antibody (dilution 1:100, clone $\mathrm{NCH}-38, \mathrm{DAKO}$ ) or rabbit polyclonal anti-WNT-1 antibody (dilution 1:100, Spring Bioscience). Negative controls were incubated with mouse or rabbit IgGs (DAKO). Subsequently, sections were incu-

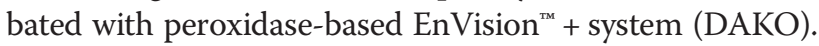
Colorectal epithelium was used as an external positive control showing strong membranous expression of Ecadherin and $\beta$-catenin.

\section{Evaluation of the staining}

The expression was scored by three independent observers (AS, SC, WK) without knowledge of the clinical data. All membranous, cytoplasmic and nuclear staining was evaluated in cancer cells. The intensity of membrane staining was categorized as follows: strongly positive when intensity was equal to the intensity of cell membrane in positive control and weakly positive corresponding to the intensities between strong and negative. The presence of cytoplasmic and nuclear staining was graded into two groups: negative and positive if $10 \%$ of tumour cells showed immunoreactivity.

\section{Statistical analysis}

Statistical analyses included descriptive statistics with determination of minimal and maximal values, means and medians, with 95\% confidence interval (CI) for particular variables. OS was defined as time elapsed between the date of diagnosis and date of death or the date of last follow-up. PFS was defined as the time from diagnosis until disease recurrence or death or date of last follow-up. A Spearman test for non-parametric variables was used to assess correlation between histoclinical data and the expression of studied proteins. A Mann-Whitney U test for non-parametric variables was used to assess if the expression of studied 
Table 1 Characteristics of patients $(n=46)$

\begin{tabular}{ll}
\hline Characteristics & $\mathbf{n}(\%)$ \\
\hline Age & \\
Median 95\% Cl (years) & $54(52.1-57.4)$ \\
Performance status (ECOG scale) & \\
0 & $6(13.1 \%)$ \\
1 & $37(80.4 \%)$ \\
2 & $3(6.5 \%)$ \\
FIGO stage at diagnosis & \\
IIIA & $4(8.7 \%)$ \\
IIIB & $8(17.4 \%)$ \\
IIIC & $20(43.5 \%)$ \\
IV & $14(30.4 \%)$ \\
Histologic cell type & \\
Serous & $24(52.2 \%)$ \\
Endometrioid & $10(21.7 \%)$ \\
Mucinous & $3(6.5 \%)$ \\
Clear cell & $2(4.3 \%)$ \\
Mixed & $6(13.1 \%)$ \\
Undifferentiated & $1(2.2 \%)$ \\
Grade & \\
G1 and G2 & \\
Resimary surgery (with interval surgery) & $21(45.6 \%)$ \\
\hline & $25(54.4 \%)$ \\
\hline & $15(32.6 \%)$ \\
\hline
\end{tabular}

proteins had any predictive value to response to chemotherapy according to RECIST criteria (version 1.0). Univariate analyses of variables influencing PFS or OS were performed by log-rank test, which identified a preliminary list of significant factors. All variables found to be significant and factors that showed a trend towards significance $(\mathrm{p}<0.1)$ in the univariate analysis were included in the multivariate analysis. Multivariate analyses of PFS and OS were performed by Cox proportional-hazards regression using the forward stepwise method. Median and life tables were computed using the product-limit estimate by the Kaplan and Meier method and the log-rank test was employed to assess the statistical significance, $\mathrm{p}$ values less than 0.05 were considered as significant. Statistical calculation was performed using the STATISTICA for Windows Version 7.0 software.

\section{Results}

Among 132 patients with epithelial ovarian cancer in our database, 46 were eligible. The main reasons for the exclusion of patients from the study were lack of access to tumour samples (71 patients) and early stage of EOC (15 patients). Patient characteristics are summarized in Table 1. Median age in the study group was 54 years $(95 \%$ CI; 52.1-57.4). The majority (69.6\%) of patients were in stage III of the disease. More than half of the patients had the serous type of ovarian cancer and poorly differentiated tumours (52.2\% and 54.4\%, respectively). Twenty-seven (58.7\%) patients underwent optimal debulking surgery (together with optional interval debulking surgery) and 67.4\% of the group was sensitive to first-line chemotherapy.

In ovarian cancer cells, membrane E-cadherin expression was strongly positive in 39 (84.8\%) patients. Moreover the presence of cytoplasmic E-cadherin was observed in tumours of almost all patients (45/46; 97.8\%). Expression of $\beta$-catenin was strong in almost half of all patients $(21 / 46 ; 45.6 \%)$. Moreover, $\beta$-catenin was present

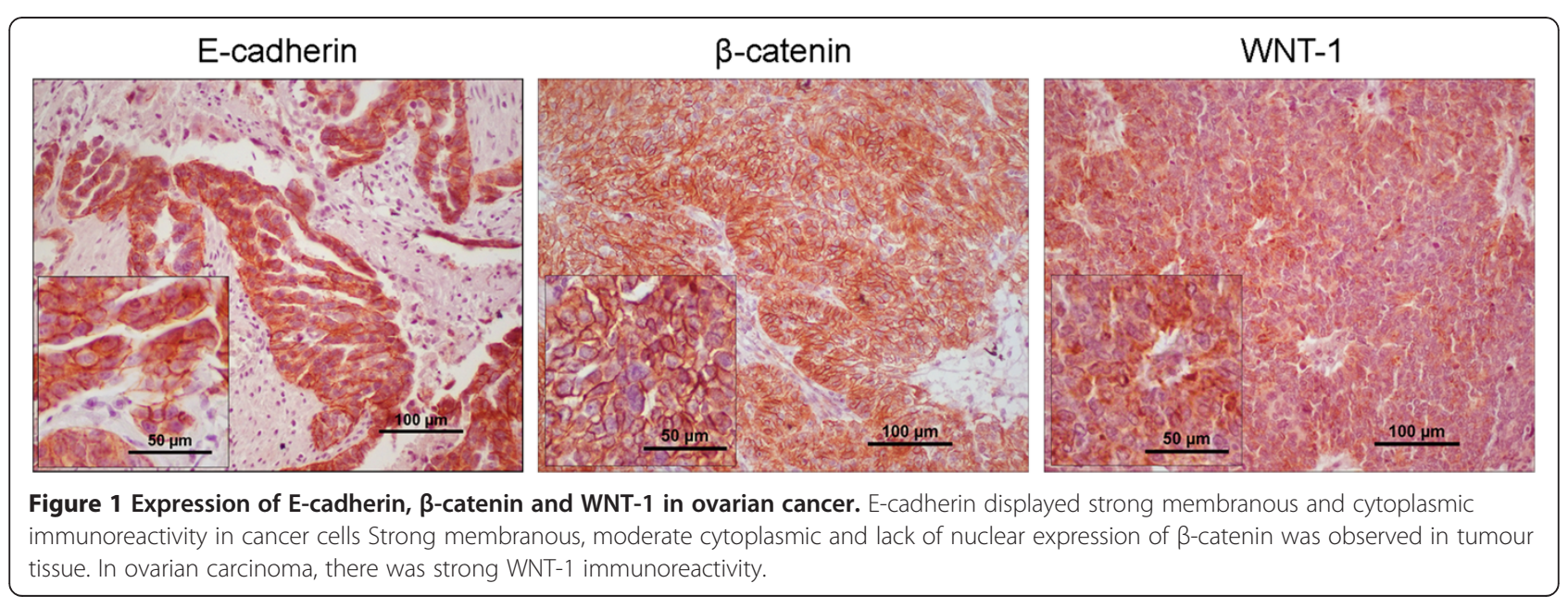


in the cytoplasm of EOC cells in 19 patients (41.3\%), while it was absent in the cell nuclei in all EOC tumours. In ovarian tumour cells, WNT-1 expression was present in $31(67.4 \%)$ women (Figure 1, Table 1).

To evaluate the impact of analysed proteins and histoclinical variables on EOC patients' outcome, univariate analysis was performed. The analysis revealed the identification of several prognostic factors for PFS such as histopathologic cell type and membranous $\beta$-catenin expression.
Age and residual tumour size revealed a prognostic trend for PFS (Table 2). Serous type of tumour was associated with shortened PFS (13.8 mo vs. 23.2 mo; $\mathrm{p}=0.028$ ). Younger age and greater residual tumour size showed a trend towards significance, while there was no association between PFS and performance status or tumour grade. Among analysed proteins, only membrane $\beta$-catenin was a prognostic factor in univariate analysis. Patients with tumours displaying strong expression of membranous $\beta$ -

Table 2 Univariate and multivariate analysis of progression-free survival

\begin{tabular}{|c|c|c|c|c|c|}
\hline \multirow{2}{*}{ Clinical parameter } & \multicolumn{3}{|c|}{ Univariate analysis } & \multicolumn{2}{|c|}{ Multivariate analysis } \\
\hline & n (\%) & Median (months) & $P$ value & HR $(95 \% \mathrm{Cl})$ & $P$ value \\
\hline \multicolumn{6}{|l|}{ Age } \\
\hline$<65$ & $38(82,6 \%)$ & 14,1 & \multirow[t]{2}{*}{0,076} & \multirow[t]{2}{*}{ NS } & \multirow[t]{2}{*}{ NS } \\
\hline$\geq 65$ & $8(17,4 \%)$ & 23,2 & & & \\
\hline \multicolumn{6}{|c|}{ Histopathologic cell type } \\
\hline Serous & $24(52,2 \%)$ & 13,8 & \multirow{2}{*}{0,028} & \multirow{2}{*}{ NS } & \multirow{2}{*}{ NS } \\
\hline Others & $22(47,8 \%)$ & 23,2 & & & \\
\hline \multicolumn{6}{|l|}{ Residual tumor size } \\
\hline$<1 \mathrm{~cm}$ & $19(41,3 \%)$ & 21,8 & \multirow[t]{2}{*}{0,054} & NS & \multirow[t]{2}{*}{ NS } \\
\hline$>1 \mathrm{~cm}$ & $27(58,7 \%)$ & 10,7 & & & \\
\hline \multicolumn{6}{|c|}{ Performance status (ECOG) } \\
\hline $0-1$ & $43(93,5 \%)$ & 16,7 & \multirow[t]{2}{*}{0,564} & & \\
\hline 2 & $3(6,5 \%)$ & 22,0 & & & \\
\hline \multicolumn{6}{|l|}{ Tumor grade } \\
\hline $\mathrm{G} 1, \mathrm{G} 2$ & $21(45,6 \%)$ & 12,9 & \multirow[t]{2}{*}{0,981} & & \\
\hline G3, unknown & $25(54,4 \%)$ & 17,5 & & & \\
\hline \multicolumn{6}{|c|}{ E-cadherin membranous } \\
\hline Negative & $7(15,2 \%)$ & 16,7 & \multirow[t]{2}{*}{0,775} & & \\
\hline Positive & $39(84,8 \%)$ & 15,9 & & & \\
\hline \multicolumn{6}{|l|}{ E-cadherin cytoplasmic } \\
\hline Negative & $1(2,2 \%)$ & & & & \\
\hline Positive & $45(97,8 \%)$ & - & - & & \\
\hline \multicolumn{6}{|c|}{$\beta$-catenin membranous } \\
\hline Normal & $21(45,6 \%)$ & 9,9 & \multirow[t]{2}{*}{0,024} & $2,19(1,09-4,39)$ & \multirow[t]{2}{*}{0,028} \\
\hline Decreased & $25(54,4 \%)$ & 22,8 & & & \\
\hline \multicolumn{6}{|l|}{$\beta$-catenin cytoplasmic } \\
\hline Negative & $27(58,7 \%)$ & 15,4 & \multirow[t]{2}{*}{0,806} & & \\
\hline Positive & $19(41,3 \%)$ & 16,7 & & & \\
\hline \multicolumn{6}{|l|}{$\beta$-catenin nuclear } \\
\hline Negative & $46(100,0 \%)$ & - & \multirow[t]{2}{*}{-} & & \\
\hline Positive & $0(0,0 \%)$ & & & & \\
\hline \multicolumn{6}{|l|}{ WNT-1 } \\
\hline Normal & $31(67,4 \%)$ & 13,5 & 0,898 & & \\
\hline Decreased & $15(32,6 \%)$ & 18,8 & & & \\
\hline
\end{tabular}

NS - non significant. 

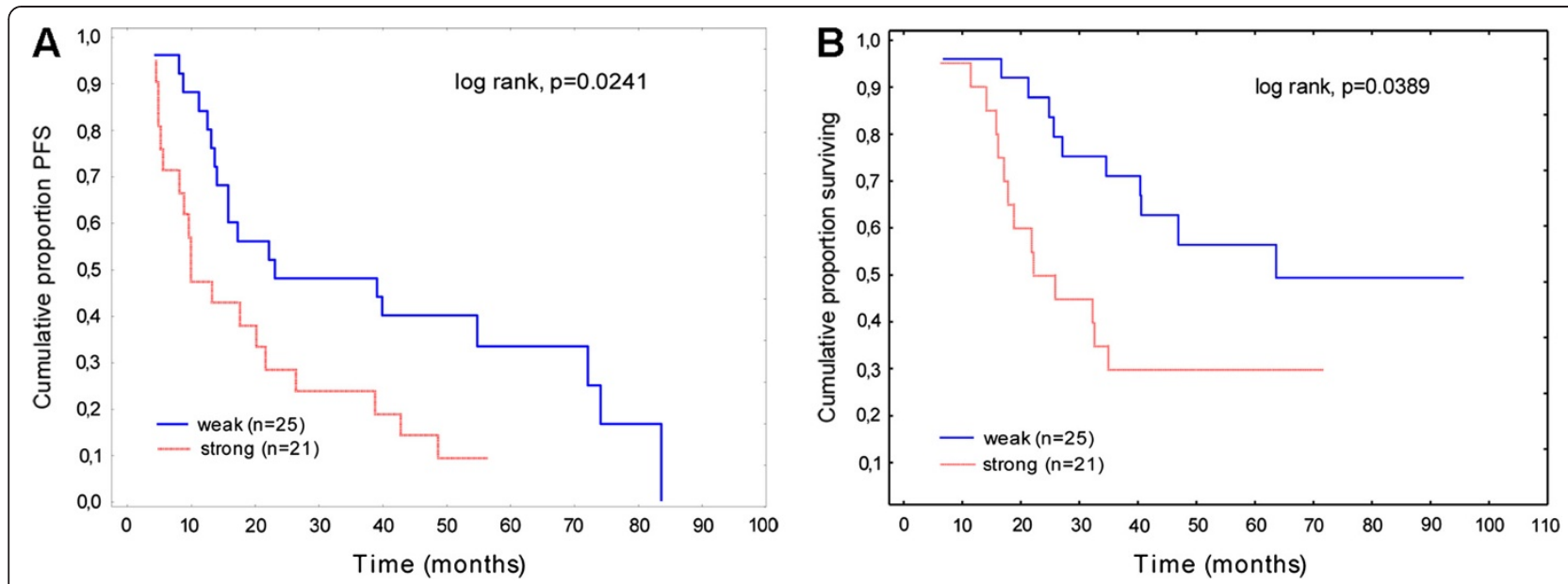

Figure 2 Kaplan-Meier curves for PFS (A) and OS (B) by expression of membranous $\beta$-catenin. Red line: strong expression of $\beta$-catenin.

Blue line: weak expression of $\beta$-catenin.

catenin had shorter PFS than patients with a decreased level of the studied protein ( 9.9 mo vs. 22.8 mo; $\mathrm{p}=0.024)$ (Figure 2). The expression of E-cadherin or WNT-1 were not associated with PFS. In the multivariate analysis, only intense expression of membrane $\beta$-catenin was an independent adverse prognostic factor for PFS (HR 2.19, 95\% CI 1.09-4.39; $\mathrm{p}=0.028$ ).

In our study, we also found prognostic factors for OS (Table 3). Patients resistant to first-line chemotherapy had shortened OS in comparison to platinum-sensitive tumours $(21.7$ mo vs. 93.4 mo; $\mathrm{p}<0.001)$. Additionally, serous ovarian carcinoma was associated with shortened OS in comparison to other subtypes (62.5 mo vs. $80.8 \mathrm{mo}$; $\mathrm{p}=0.043)$. Among analysed proteins, only strong expression of membrane $\beta$-catenin was a prognostic factor for shortened OS in univariate analysis (22.2 mo vs. $62.2 \mathrm{mo}$; $\mathrm{p}=0.039$; Figure 2). Residual tumour size showed a trend towards significance, while there was no association between OS and age, performance status or tumour grade. In the multivariate analysis, only resistance to firstline chemotherapy was an unfavourable prognostic factor (HR 16.84; 95\% CI 5.07-55.98; $\mathrm{p}<0.0001$ ).

We analysed the association between the intense expression of membrane $\beta$-catenin and the response to chemotherapy in the 29 patients with measurable disease according to RECIST criteria (version 1.0). There was a difference observed in complete response (CR), partial response $(\mathrm{PR})$, stable disease (SD) and progressive disease (PD) distribution according to membrane $\beta$-catenin expression $(\mathrm{p}=0.044)$. Eight $(61.5 \%)$ EOC patients with tumours demonstrating strong $\beta$-catenin expression in the cell membrane had SD or PD, while most of the patients (14/16; 87.5\%) with tumours displaying weak membrane $\beta$-catenin expression had an objective response $(\mathrm{CR}+\mathrm{PR})$ that was statistically significant $(\mathrm{p}=0.027$; Table 4$)$.

\section{Discussion}

In the present study, we analysed the expression of Ecadherin, $\beta$-catenin and WNT-1 in advanced ovarian carcinoma. We demonstrated the presence of E-cadherin expression both in the cell membrane and cytoplasm of ovarian tumour cells. The expression of E-cadherin has been investigated in ovarian carcinoma, but in most of the studies, patients in different stages of the disease were examined $[24,28]$. According to the published data, in the majority of cases of ovarian cancer, E-cadherin is upregulated unlike other type of cancers, where E-cadherin expression is decreased [18]. Ovarian surface epithelium displays epithelial and mesenchymal characteristics and does not contain E-cadherin, but rather expresses $\mathrm{N}$-cadherin [22,29-32].

In primary and well-differentiated cancers E-cadherin expression is high, while in advanced EOC, E-cadherin expression is moderate, although complete loss of E-cadherin is rare [22,23,25,28-30,33]. Moreover, E-cadherin was found in small cohesive tumour nodules floating in the peritoneal cavity, in metastatic lesions and effusion specimens [34-36]. We suggest that in metastatic cancer cells, E-cadherin expression is required for cell survival. There are several studies documenting that E-cadherin contributes to activation of the PI3K/AKT signalling pathway, which controls cellular survival and proliferation [37-39]. In ovarian cancer cell lines, E-cadherin allows the recruitment of PI3K-p85 regulatory subunit to the cell membrane, leading to the activation of the p110 catalytic subunit following signal transduction [39]. Additionally, E-cadherin could also activate the MAPK pathway through RAF [38]. These data indicate that E-cadherin may be important for ovarian cancer cell survival.

Furthermore, we detected intense expression of membrane $\beta$-catenin in advanced EOC. Our results are 
Table 3 Univariate and multivariate analysis of overall survival

\begin{tabular}{|c|c|c|c|c|c|}
\hline \multirow[t]{2}{*}{ Clinical parameter } & \multicolumn{3}{|c|}{ Univariate analysis } & \multicolumn{2}{|c|}{ Multivariate analysis } \\
\hline & n (\%) & Median (months) & $P$ value & HR $(95 \% \mathrm{Cl})$ & $P$ value \\
\hline Age & & & 0,248 & & \\
\hline$<65$ & $38(82,6 \%)$ & $70,1 \%$ & & & \\
\hline$\geq 65$ & $8(17,4 \%)$ & $75,0 \%$ & & & \\
\hline Histopathologic cell type & & & $0,043^{*}$ & NS & NS \\
\hline Serous & $24(52,2 \%)$ & $62,5 \%$ & & & \\
\hline Others & $22(47,8 \%)$ & $80,8 \%$ & & & \\
\hline Residual tumor size & & & 0,134 & & \\
\hline$<1 \mathrm{~cm}$ & $19(41,3 \%)$ & $81,1 \%$ & & & \\
\hline$>1 \mathrm{~cm}$ & $27(58,7 \%)$ & $55,9 \%$ & & & \\
\hline Performance status (ECOG) & & & 0,276 & & \\
\hline $0-1$ & $43(93,5 \%)$ & $71,2 \%$ & & & \\
\hline 2 & $3(6,5 \%)$ & $66,6 \%$ & & & \\
\hline Tumor grade & & & 0,498 & & \\
\hline G1, G2 & $21(45,6 \%)$ & 32,6 & & & \\
\hline G3, unknown & $25(54,4 \%)$ & 40,4 & & & \\
\hline Sensitivity to first-line chemotherapy & & & $<0,0001^{*}$ & $16,84(5,07-55,98)$ & $<0,0001^{*}$ \\
\hline Resistant (<6 months) & $26(35,1 \%)$ & $21,7 \%$ & & & \\
\hline Sensitive (>6 months) & $48(64,9 \%)$ & $93,4 \%$ & & & \\
\hline E-cadherin membranous & & & 0,472 & & \\
\hline Negative & $7(15,2 \%)$ & 50,0 & & & \\
\hline Positive & $39(84,8 \%)$ & 35,7 & & & \\
\hline E-cadherin cytoplasmic & $1(2,2 \%)$ & - & - & & \\
\hline Negative & $45(97,8 \%)$ & & & & \\
\hline \multicolumn{6}{|l|}{ Positive } \\
\hline$\beta$-catenin membranous & & & $0,039 *$ & NS & NS \\
\hline Normal & $21(45,6 \%)$ & 22,2 & & & \\
\hline Decreased & $25(54,4 \%)$ & 62,2 & & & \\
\hline$\beta$-catenin cytoplasmic & & & 0,916 & & \\
\hline Negative & $27(58,7 \%)$ & 32,6 & & & \\
\hline Positive & $19(41,3 \%)$ & 40,1 & & & \\
\hline$\beta$-catenin nuclear & & - & - & & \\
\hline Negative & $46(100,0 \%)$ & & & & \\
\hline Positive & $0(0,0 \%)$ & & & & \\
\hline WNT-1 & & & 0,846 & & \\
\hline Normal & $31(67,4 \%)$ & 33,7 & & & \\
\hline Decreased & $15(32,6 \%)$ & 40,5 & & & \\
\hline
\end{tabular}

\#If median was not achieved, the results were described as a percentage of patients with 2-year OS; NS- non significant; ${ }^{*}$ The value of the probability of a statistically significant $(\mathrm{p}<0.05)$; Cl-confidence interval; HR- hazard ratio; ECOG- The Eastern Cooperative Oncology Group scale of performance status.

concordant with earlier reports showing positive $\beta$ catenin expression in ovarian tumours, but they differ from the results reported by other groups where the expression of $\beta$-catenin was decreased [23,25]. Additionally, Davidson et al. found that although there was no difference in the intensity of $\beta$-catenin expression, there was a reduction in the number of cells expressing membranous $\beta$-catenin [33]. These results suggest that expression of $\beta$ catenin is maintained in advanced ovarian carcinomas, but at a moderate level. In vitro studies showed that shRNAmediated silencing of $\beta$-catenin resulted in inhibition of proliferation and decreased capability of colony formation 
Table 4 Association between membrane $\beta$-catenin expression and response to chemotherapy in patients according to RECIST criteria (version 1.0)

\begin{tabular}{|c|c|c|c|c|c|}
\hline \multirow{3}{*}{$\begin{array}{l}\text { Response to to chemotherapy } \\
\text { according to to RECIST }\end{array}$} & \multirow{2}{*}{\multicolumn{2}{|c|}{$\begin{array}{l}\text { Normal membrane } \beta \text {-catenin expression } \\
(\mathrm{n}=13)\end{array}$}} & \multirow{2}{*}{\multicolumn{2}{|c|}{$\frac{\text { Decreased membrane } \beta \text {-catenin expression }}{(n=16)}$}} & \multirow{3}{*}{$\begin{array}{l}\text { Mann-Whitney } \\
U \text { test } \\
P \text { value }\end{array}$} \\
\hline & & & & & \\
\hline & $\mathrm{n}$ & $\%$ & $\mathrm{n}$ & $\%$ & \\
\hline $\mathrm{OR}(\mathrm{CR}+\mathrm{PR})$ & 5 & 38.5 & 14 & 87.5 & $0.027^{*}$ \\
\hline $\mathrm{SD}+\mathrm{PD}$ & 8 & 61.5 & 2 & 12.5 & \\
\hline$C R$ & 5 & 38.5 & 13 & 81.25 & $0.044^{*}$ \\
\hline PR & 0 & 0.0 & 1 & 6.25 & \\
\hline SD & 6 & 46.1 & 1 & 6.25 & \\
\hline PD & 2 & 15.4 & 1 & 6.25 & \\
\hline
\end{tabular}

Abbreviations: *The value of the probability of a statistically significant ( $p<0.05)$; RECIST - Response Evaluation Criteria In Solid Tumours; CR - Complete Response; PR - Partial Response; SD - Stable Disease; PD - Progressive Disease.

in A2780 ovarian cancer cells [40]. On the basis of these studies, one can speculate that $\beta$-catenin is required for proliferation of ovarian cancer cells. A similar effect was observed in colorectal cancer, lung cancer and glioblastoma cells [41-43]. It means that the presence of $\beta$-catenin might be required for proliferation and migration, but the precise mechanism is still unknown and should be determined.

$\beta$-catenin is also a key component of the signalling pathway that is activated by WNT ligands. We showed that in most of the ovarian tumours, there was a strong WNT-1 expression; however, no nuclear $\beta$-catenin was found. It might suggest that the $\mathrm{WNT} / \beta$-catenin signalling pathway was not activated despite the presence of WNT-1 ligand. WNT-1 expression has been detected in ovarian carcinomas [26,44]; however, other WNT ligands were also found such as WNT-5a, which was highly expressed in EOC tumours [26,45]. Yoshioka et al. studied expression of all WNT ligands at the mRNA level in ovarian tumours. They found that WNT-3 and WNT-4 expression was reduced, while expression of WNT-7a and WNT-7b was increased [46]. Additionally WNT-7a increased expression was confirmed at the protein level [46]. In humans, the WNT protein family consists of 19 ligands that can play a different role in signal transduction. For example, WNT-1 and WNT-2 activates the canonical WNT pathway, where $\beta$-catenin is a key protein, whereas WNT-5a, WNT-7a and WNT-7b activate non-canonical pathways including the planar cell polarity pathway or WNT/Ca2+ pathway [47-49]. In ovarian cancers, both types of ligand were found, which implicates that canonical and non-canonical WNT pathways could control ovarian carcinogenesis. Thus, further analysis of all WNT ligands on a larger group of EOC patients is needed.

In our study, we found prognostic factors for OS and PFS of EOC patients and predictors for chemotherapy response. We revealed that strong membrane $\beta$-catenin expression was an independent adverse prognostic factor for PFS, while only resistance to first-line chemotherapy was an unfavourable prognostic factor for OS of advanced ovarian cancer patients. Davidson et al. also investigated the influence of $\beta$-catenin expression on advanced EOC patient survival, but they did not find any statistically significant correlation [33]. However, low membrane expression of $\beta$-catenin was shown to be an adverse prognostic factor for OS of patients in different stages of the disease $[27,28]$. On the other hand, preserved expression of membrane $\beta$-catenin was associated with 10-year diseaserelated survival and favourable recurrence-free survival of EOC patients in univariate analysis [25]. Discordance between these results and ours could be due to differences between the pattern of gene expression in the advanced ovarian cancer and tumours confined to the primary site. Shirdar et al. investigated genetic differences between stages I/II and III/IV of ovarian tumours [50,51]. They found that in advanced ovarian cancers, there were more chromosomal gains and gene amplifications compared to early carcinomas. Additionally, it has been reported that activation and overexpression of BTAK/Aurora-A, which is essential for chromosome segregation and centrosome function, was associated with early stage EOC, while activation of phosphorylated AKT or SRC was associated with advanced-stage disease [52-54]. The variety of genetic features in early and advanced ovarian cancers may result in a complex array of prognostic factors.

Finally, we found that strong membranous $\beta$-catenin expression was associated with the lack of response to chemotherapy, which corroborates in vitro studies. Silencing of $\beta$-catenin leads to the increased sensitivity of A2780 ovarian cancer cells to cisplatin, paclitaxel and vincristine [40]. Moreover, metastatic melanoma cells with $\beta$-catenin knocked down are more sensitive to cisplatin, temozolomide and doxorubicin [55]. In addition, cisplatin-resistant laryngeal carcinoma cells have increased expression of $\beta$-catenin in the cell membrane [56]. It suggests that expression of $\beta$-catenin might be associated with the response to chemotherapy. Due to $\beta$-catenin being observed in the cell membrane, but not in the 
cell nuclei, we speculate that $\beta$-catenin present in adherent junctions could be important in drug response. One of the known mechanisms of drug resistance is the cell-adhesion-mediated drug resistance (CAM-DR). The association between cell adhesion and resistance of tumour cells to anticancer agents was observed for the first time by Sutherland [57]. Further studies showed correlation between the expression of cell adhesion molecules and drug resistance: collagen VI, collagen XIA1 and connexin 43 were upregulated in cisplatin-resistant ovarian carcinoma cells [58,59], while high expression of claudin-7 was associated with a poor response to platinumbased chemotherapy in EOC patients [60]. Additionally, $25 \%$ of overexpressed proteins identified in the carboplatinand paclitaxel-resistant tissues are the components of the extracellular matrix (i.e. $\gamma$-catenin, $\delta$-catenin) [61]. A range of proteins involved in cellular adhesion, including $\beta$-catenin, may become new predictors of response to platinum-based chemotherapy in ovarian carcinoma, but more evidence showing their usefulness is needed.

\section{Conclusions}

In conclusion, our study showed the presence of $\beta$ catenin and E-cadherin expression in advanced ovarian cancers. Our results imply that $\beta$-catenin and E-cadherin expression may be required for ovarian carcinogenesis because these proteins are involved in signalling pathways that control cell proliferation. Additionally, $\beta$-catenin could be responsible for resistance to chemotherapy, because some cell adhesion proteins are associated with resistance of tumour cells to chemotherapy. Moreover, we speculate that canonical and non-canonical WNT pathways could control ovarian carcinogenesis, because $\beta$ catenin is absent in cancer cell nuclei, despite a strong WNT-1 expression. These findings support that WNT/ $\beta$ catenin pathway, as well E-cadherin, are important in advanced epithelial ovarian cancer.

\section{Abbreviations \\ APC: Anaphase promoting complex; $\beta \operatorname{TrCP}$ : Ubiquitin ligase protein; CA-125: Cancer antigen 125; CAM-DR: Cell-adhesion-mediated drug resistance; $\mathrm{Cl}$ : Confidence interval; CKI: Casein kinase I; CR: Complete response; EOC: Epithelial ovarian cancer; FIGO: International Federation of Gynaecology and Obstetrics; FZD/LRP: Frizzled/lipoprotein receptor-related protein; GSK3 $\beta$ : Glycogen synthase kinase 3 $\beta$; OS: Overall survival; PD: Progressive disease; PFS: Progression-free survival; PR: Partial response; SD: Stable disease; TCF/LEF: T-cell factor/lymphoid enhancer factor.}

\section{Competing interests}

All authors declare that they have no competing interests.

\section{Authors' contributions}

LB participated in acquisition of data, performed the statistical analysis and wrote the manuscript. AS carried out immunohistochemical analyses and evaluation of the staining, and wrote the manuscript. SC carried out evaluation of the staining. MS participated in acquisition of data. MC carried out immunohistochemical analyses. WK carried out evaluation of the staining. CS conceived of the study and participated in its design and coordination. MW conceived of the study and participated in its design and coordination and helped to draft the manuscript. MLP conceived of the study and participated in its design and coordination and helped to draft the manuscript. All authors read and approved the final manuscript.

\section{Acknowledgement}

This work was supported in part by a grant from Military Institute of Medicine in Warsaw and by Celon Pharma Inc.

\section{Author details}

'Department of Oncology, Military Institute of Medicine in Warsaw, 128 Szaserów Street, 04-141 Warsaw, Poland. ${ }^{2}$ Innovative Drugs Research \& Development Department, Celon Pharma Inc, Lomianki, Poland. ${ }^{3}$ Department of Pathology, Military Institute of Medicine in Warsaw, 128 Szaserów Street, 04-141 Warsaw, Poland.

Received: 5 November 2013 Accepted: 25 January 2014

Published: 6 February 2014

\section{References}

1. Lee KR, Tavassoli FA, Prat J, Dietel M, Gersell DJ, Karseladze Al, Hauptmann S, Rutgers J, Russell P, Buckley CH, Pisani P, Schwartz P, Goldgar DE, Silva E, Caduf R, Kubik-Huch RA: Surface epithelial-stromal tumours. In World Health Organization Classification of Tumours. Pathology and Genetics of Tumours of the Breast and Female Genital Organs. Edited by Tavassoli FA, Devilee P. Lyon: IARCPress; 2003:113-202.

2. Ferlay J, Shin HR, Bray F, Forman D, Mathers C, Parkin DM: GLOBOCAN 2008 V1.2, Cancer Incidence and Mortality Worldwide: IARC CancerBase No. 10 [Internet]. Lyon, France: International Agency for Research on Cancer; 2010. http://globocan.iarc.fr.

3. Siegel R, Naishadham D, Jemal A: Cancer statistics, 2012. CA Cancer J Clin 2012, 62:10-29.

4. Classe JM, Fontanelli R, Bischof-Delaloye A, Chatal JF: Ovarian cancer management. Practice guidelines for nuclear physicians. Q J Nucl Med Mol Imaging 2004, 48:143-149.

5. Aebi S, Castiglione M, ESMO Guidelines Working Group: Newly and relapsed epithelial ovarian carcinoma: ESMO clinical recommendations for diagnosis, treatment and follow-up. Ann Oncol 2009, 20(Suppl 4):21-23.

6. Jacobs I, Bast RC Jr: The CA125 tumour associated antigen: a review of the literature. Hum Reprod 1989, 4:1-12

7. Hawkins RE, Roberts K, Wiltshaw E, Mundy J, Fryatt IJ, McCready VR: The prognostic significance of the half-life of serum CA 125 in patients responding to chemotherapy for epithelial ovarian carcinoma. $\mathrm{Br} J$ Obstet Gynaecol 1989, 6:1395-1399.

8. Gadducci A, Zola P, Landoni F, Maggino T, Sartori E, Bergamino T, Cristofani R: Serum half-life of CA125 during early chemotherapy as an independent prognostic variable for patients with advanced epithelial ovarian cancer: results of a multicentric Italian study. Gynecol Oncol 1995, 58:42-47.

9. Vasudev NS, Trigonis I, Cairns DA, Hall GD, Jackson DP, Broadhead T, Buxton J, Hutson R, Nugent D, Perren TJ: The prognostic and predictive value of CA-125 regression during neoadjuvant chemotherapy for advanced ovarian or primary peritoneal carcinoma. Arch Gynecol Obstet 2011, 284:221-227.

10. Gadducci A, Cosio S, Fanucchi A, Negri S, Cristofani R, Genazzani AR: The predictive and prognostic value of serum CA 125 halflife during paclitaxel/platinum-based chemotherapy in patients with advanced ovarian carcinoma. Gynecol Oncol 2004, 93:131-136.

11. Riedinger JM, Eche N, Basuyau JP, Dalifard I, Hacene K, Pichon MF: Prognostic value of serum CA 125 bi-exponential decrease during first line paclitaxel/platinum chemotherapy: a French multicentric study. Gynecol Oncol 2008, 109:194-198.

12. Moon RT, Kohn AD, De Ferrari GV, Kaykas A: WNT and beta-catenin signalling: diseases and therapies. Nat Rev Genet 2004, 5:691-701.

13. Gadducci A, Cosio S, Tana R, Genazzani AR: Serum and tissue biomarkers as predictive and prognostic variables in epithelial ovarian cancer. Crit Rev Oncol Hematol 2009, 69:12-27.

14. Gatcliffe TA, Monk BJ, Planutis K, Holcombe RF: Wnt signaling in ovarian tumorigenesis. Int J Gynecol Cancer 2008, 18:954-962.

15. Aberle H, Schwartz H, Kemler R: Cadherin-catenin complex: protein interactions and their implications for cadherin function. $J$ Cell Biochem 1996, 61:514-523. 
16. Wnt Homepage. Stanford: The Nusse Laboratory, Stanford School of Medicine [http://www.stanford.edu/group/nusselab/cgi-bin/wnt/ target_genes]

17. Polakis P: The many ways of Wnt in cancer. Curr Opin Genet Dev 2007, 17:45-51.

18. Berx G, van Roy F: Involvement of members of the cadherin superfamily in cancer. Cold Spring Harb Perspect Biol 2009, 1:a003129.

19. Palacios J, Gamallo C: Mutations in the beta-catenin gene (CTNNB1) in endometrioid ovarian carcinomas. Cancer Res 1998, 58:1344-1347.

20. Gamallo C, Palacios J, Moreno G, Calvo de Mora J, Suarez A, Armas A: beta-catenin expression pattern in stage I and II ovarian carcinomas: Relationship with beta catenin gene mutations, clinicopathological features, and clinical outcome. Am J Pathol 1999, 155:527-536.

21. Wright K, Wilson P, Morland S, Campbell I, Walsh M, Hurst T, Ward B, Cummings $\mathrm{M}$, Chenevix-Trench $\mathrm{G}$ : beta-catenin mutation and expression analysis in ovarian cancer: Exon 3 mutations and nuclear translocation in 16\% of endometrioid tumours. Int J Cancer 1999, 82:625-629.

22. Davies BR, Worsley SD, Ponder BA: Expression of E-cadherin, alpha-catenin and beta-catenin in normal ovarian surface epithelium and epithelial ovarian cancers. Histopathology 1998, 32:69-80.

23. Imai T, Horiuchi A, Shiozawa T, Osada R, Kikuchi N, Ohira S, Oka K, Konishi I: Elevated expression of E-cadherin and alpha-, beta-, and gamma-catenins in metastatic lesions compared with primary epithelial ovarian carcinomas. Hum Pathol 2004, 35:1469-1476.

24. Sarrió D, Moreno-Bueno G, Sánchez-Estévez C, Bañón-Rodríguez I, HernándezCortés G, Hardisson D, Palacios J: Expression of cadherins and catenins correlates with distinct histologic types of ovarian carcinomas. Hum Pathol 2006, 37:1042-1049.

25. Voutilainen KA, Anttila MA, Sillanpää SM, Ropponen KM, Saarikoski SV, Juhola MT, Kosma VM: Prognostic significance of E-cadherin-catenin complex in epithelial ovarian cancer. J Clin Pathol 2006, 59:460-467.

26. Badiglian Filho L, Oshima CT, De Oliveira LF, De Oliveira CH, De Sousa DR, Gomes TS, Gonçalves WJ: Canonical and noncanonical Wnt pathway: a comparison among normal ovary, benign ovarian tumor and ovarian cancer. Oncol Rep 2009, 21:313-320.

27. Rosen DG, Zhang Z, Chang B, Wang X, Lin E, Liu J: Low membranous expression of beta-catenin and high mitotic count predict poor prognosis in endometrioid carcinoma of the ovary. Mod Pathol 2010, 23:113-122.

28. Faleiro-Rodrigues C, Macedo-Pinto I, Pereira D, Lopes CS: Prognostic value of E-cadherin immunoexpression in patients with primary ovarian carcinomas. Ann Oncol 2004, 15:1535-1542.

29. Peralta-Soler A, Knudsen KA, Tecson-Miguel A, McBrearty FX, Han AC, Salazar H: Expression of E-cadherin and Ncadherin in surface epithelial stromal tumors of the ovary distinguishes mucinous from serous and endometrioid tumors. Human Path 1997, 28:734-739.

30. Sundfeldt K, Piontkewitz Y, Ivarsson K, Nilsson O, Hellberg P, Brännström M, Janson PO, Enerback S, Hedin L: E-cadherin expression in human epithelial ovarian cancer and normal ovary. Int J Cancer 1997, 74:275-280.

31. Wong AS, Maines-Bandiera SL, Rosen B, Wheelock MJ, Johnson KR, Leung PC, Roskelley CD, Auersperg N: Constitutive and conditional cadherin expression in cultured human ovarian surface epithelium: influence of family history of ovarian cancer. Int J Can 1999, 81:180-188.

32. Sundfeldt K: Cell-cell adhesion in the normal ovary and ovarian tumors of epithelial origin; an exception to the rule. Mol Cell Endocrinol 2003, 202:89-96.

33. Davidson B, Gotlieb WH, Ben-Baruch G, Nesland JM, Bryne M, Goldberg I, Kopolovic J, Berner A: E-Cadherin complex protein expression and survival in ovarian carcinoma. Gynecol Oncol 2000, 79:362-371.

34. Flam F, Einhorn N, Sjövall K: Symptomatology of ovarian cancer. Eur J Obstet Gynecol Reprod Biol 1988, 27:53-57.

35. Davidson B, Berner A, Nesland JM, Risberg B, Berner HS, Tropè CG, Kristensen GB, Bryne M, Ann Florenes V: E-cadherin and alpha-, beta-, and gamma-catenin protein expression is up-regulated in ovarian carcinoma cells in serous effusions. J Pathol 2000, 192:460-469.

36. Naora $\mathrm{H}$, Montell DJ: Ovarian cancer metastasis: integrating insights from disparate model organisms. Nat Rev Cancer 2005, 5:355-366.

37. Pece S, Chiariello M, Murga C, Gutkind JS: Activation of the protein kinase Akt/PKB by the formation of E-cadherin-mediated cell-cell junctions. Evidence for the association of phosphatidylinositol 3-kinase with the E-cadherin adhesion complex. J Biol Chem 1999, 274:19347-19351.
38. Reddy P, Liu L, Ren C, Lindgren P, Boman K, Shen Y, Lundin E, Ottander U, Rytinki M, Liu K: Formation of E-cadherin-mediated cell-cell adhesion activates AKT and mitogen activated protein kinase via phosphatidylinositol 3 kinase and ligand-independent activation of epidermal growth factor receptor in ovarian cancer cells. Mol Endocrinol 2005, 19:2564-2578.

39. De Santis G, Miotti S, Mazzi M, Canevari S, Tomassetti A: E-cadherin directly contributes to PI3K/AKT activation by engaging the PI3K-p85 regulatory subunit to adherens junctions of ovarian carcinoma cells. Oncogene 2009, 28:1206-1217.

40. Wang J, Zhou D, He X, Wang Y, Hu W, Jiang L, Dou J: Effect of downregulated $\beta$-catenin on cell proliferative activity, the sensitivity to chemotherapy drug and tumorigenicity of ovarian cancer cells. Cell Mol Biol (Noisy-le-grand) 2011, 57(Suppl):OL1606-OL1613.

41. Stein U, Arlt F, Walther W, Smith J, Waldman T, Harris ED, Mertins SD, Heizmann CW, Allard D, Birchmeier W, Schlag PM, Shoemaker RH: The metastasis-associated gene S100A4 is a novel target of beta-catenin/T-cell factor signaling in colon cancer. Gastroenterology 2006, 131:1486-1500.

42. Pu P, Zhang Z, Kang C, Jiang R, Jia Z, Wang G, et al: Downregulation of Wnt2 and beta-catenin by siRNA suppresses malignant glioma cell growth. Cancer Gene Ther 2009, 16:351-361.

43. Teng $Y$, Wang $X$, Wang $Y$, Ma $D$ : Wnt/beta-catenin signaling regulates cancer stem cells in lung cancer A549 cells. Biochem Biophys Res Commun 2010, 392:373-379.

44. Xiao L, Zhuo-ying $\mathrm{H}$ : Expression of Wnt-1, beta-catenin and c-myc in ovarian epithelial tumor and its implication. Chin J Cancer Res 2008, 20:73-76.

45. Peng C, Zhang X, Yu H, Wu D, Zheng J: Wnt5a as a predictor in poor clinical outcome of patients and a mediator in chemoresistance of ovarian cancer. Int J Gynecol Cancer 2011, 21:280-288.

46. Yoshioka S, King ML, Ran S, Okuda H, MacLean JA 2nd, McAsey ME, Sugino $N$, Brard L, Watabe K, Hayashi K: WNT7A regulates tumor growth and progression in ovarian cancer through the WNT/ $\beta$-catenin pathway. $\mathrm{Mol}$ Cancer Res 2012, 10:469-482.

47. Kohn AD, Moon RT: Wnt and calcium signaling: beta-cateninindependent pathways. Cell Calcium 2012, 38:439-446.

48. Jenny A, Mlodzik M: Planar cell polarity signaling: a common mechanism for cellular polarization. Mt Sinai J Med 2006, 73:738-750.

49. Kikuchi A, Yamamoto H, Sato A: Selective activation mechanisms of Wnt signaling pathways. Trends Cell Biol 2009, 19:119-129.

50. Shridhar V, Lee J, Pandita A, Iturria S, Avula R, Staub J, Morrissey M, Calhoun E, Sen A, Kalli K, Keeney G, Roche P, Cliby W, Lu K, Schmandt R, Mills GB, Bast RC Jr, James CD, Couch FJ, Hartmann LC, Lillie J, Smith DI: Genetic analysis of early- versus late-stage ovarian tumors. Cancer Res 2001, 61:5895-5904.

51. Shridhar V, Sen A, Chien J, Staub J, Avula R, Kovats S, Lee J, Lillie J, Smith DI: Identification of underexpressed genes in early- and late-stage primary ovarian tumors by suppression subtraction hybridization. Cancer Res 2002, 62:262-270.

52. Gritsko TM, Coppola D, Paciga JE, Yang L, Sun M, Shelley SA, Fiorica JV, Nicosia SV, Cheng JQ: Activation and overexpression of centrosome kinase BTAK/Aurora-A in human ovarian cancer. Cancer Res 2003, 9:1420-1426.

53. Wiener JR, Windham TC, Estrella VC, Parikh NU, Thall PF, Deavers MT, Bast RC, Mills GB, Gallick GE: Activated SRC protein tyrosine kinase is overexpressed in late-stage human ovarian cancers. Gynecol Oncol 2003, 88:73-79.

54. de Graeff P, Crijns AP, Ten Hoor KA, Klip HG, Hollema H, Oien K, Bartlett JM, Wisman GB, de Bock GH, de Vries EG, de Jong S, van der Zee AG: The ErbB signalling pathway: protein expression and prognostic value in epithelial ovarian cancer. Br J Cancer 2008, 99:341-349.

55. Sinnberg T, Menzel M, Ewerth D, Sauer B, Schwarz M, Schaller M, Garbe C, Schittek $B$ : $\beta$-Catenin signaling increases during melanoma progression and promotes tumor cell survival and chemoresistance. PLoS One 2011, 6:e23429.

56. Cimbora-Zovko T, Ambriović-Ristov A, Loncarek J, Osmak M: Altered cell-cell adhesion in cisplatin-resistant human carcinoma cells: a link between beta-catenin/plakoglobin ratio and cisplatin resistance. Eur J Pharmacol 2007, 558:27-36.

57. Sutherland RM: Cell and environment interactions in tumor microregions: the multicell spheroid model. Science 1988, 240:177-184.

58. Sherman-Baust CA, Weeraratna AT, Rangel LB, Pizer ES, Cho KR, Schwartz $D R$, Shock T, Morin: Remodeling of the extracellular matrix through 
overexpression of collagen $\mathrm{VI}$ contributes to cisplatin resistance in ovarian cancer cells. Cancer Cell PJ 2003, 3:377-386.

59. Li J, Wood WH 3rd, Becker KG, Weeraratna AT, Morin PJ: Gene expression response to cisplatin treatment in drug-sensitive and drug-resistant ovarian cancer cells. Oncogene 2007, 26:2860-2872.

60. Kim CJ, Lee JW, Choi JJ, Choi HY, Park YA, Jeon HK, Sung CO, Song SY, Lee YY, Choi CH, Kim TJ, Lee JH, Kim BG, Bae DS: High claudin-7 expression is associated with a poor response to platinum-based chemotherapy in epithelial ovarian carcinoma. Eur J Cancer 2011, 47:918-925.

61. Pan S, Cheng L, White JT, Lu W, Utleg AG, Yan X, Urban ND, Drescher CW, Hood L, Lin B: Quantitative proteomics analysis integrated with microarray data reveals that extracellular matrix proteins, catenins, and p53 binding protein 1 are important for chemotherapy response in ovarian cancers. OMICS 2009, 13:345-354.

doi:10.1186/1757-2215-7-16

Cite this article as: Bodnar et al: Wnt/ $\beta$-catenin pathway as a potential prognostic and predictive marker in patients with advanced ovarian cancer. Journal of Ovarian Research 2014 7:16.

\section{Submit your next manuscript to BioMed Central and take full advantage of:}

- Convenient online submission

- Thorough peer review

- No space constraints or color figure charges

- Immediate publication on acceptance

- Inclusion in PubMed, CAS, Scopus and Google Scholar

- Research which is freely available for redistribution 